\title{
THE TREATMENT OF LIME BURNS OF THE CORNEA BY $10 \%$ NEUTRAL AMMONIUM TARTRATE
}

BY

\author{
E. WOLFF \\ LONDON
}

OF all burns of the cornea the one that is generally held to have the worst prognosis is that due to lime. For in this burn there are two factors which produce the resultant opacity. Not only does the caustic effect of the lime destroy the corneal tissue with resultant nebula, but the lime also combines with the tissues of the cornea to form particles of calcium carbonate. As time goes on this second element in the opacity tends if anything to increase. The nebula resulting from the actual burn can only be treated by surgical means-no chemical agents, as far as one is aware, have any effect on it. It is happily different with the second element in the opacity.

As far back as 1905 zur Nedden recommended the use of 10 per cent. neutral ammonium tartrate for the removal of the calcium carbonate, and published successful cases. Since then up to the time I first started its use I find no mention of it in the literature and although it is recommended in various text-books, for instance those of Fuchs and Parsons, it has remained practically unknown.*

The first case was seen at University College Hospital on February 4,1924 . The patient, H.F., a young man, aged 26 years, a plasterer by trade, had a severe burn of the cornea the result of cement containing lime entering his right eye four days before admission. He was in much pain and the eye was lacrimating freely. There was much ciliary and conjunctival injection. The cornea stained with fluorescine almost over the whole of its extent and was typically cloudy in appearance. On examining it with a loupe the characteristic white spots of calcium carbonate could be seen.

The eye was cocainized for ten minutes with 4 per cent. cocain (for the drug is at first far too painful without this preliminary treatment) and freshly prepared 10 per cent. neutral ammonium

\footnotetext{
*I have just, however, received a reprint of an article on the same subject with similar results by Drs. O. and $\mathrm{H}$. Barkan, of San Francisco, Jl. of Amer. Med. Assoc., Vol. LXXXIII, pp. 1567-1569, Nov., 1924. They give the following references :-

1. Guillery.-Ueber die Kalktrübung der Hornhaut und Verfahren zu ihrer Aufhellung. Arch.f. Augenheilk., Feb., 1902.

2. zur Nedden.- Ueber Aufhellung von Blei und Kalk Trübungen der Hornhaut. Heidelberg Congress, p. 216, 1905.

3. Fuchs, E.-Bericht ueber die 32te Verzammlung der Ophthalmologischen Gessellschaft. Discussion, p. 225. Heidelberg, 1905.
} 
tartrate slowly instilled with an undine for about fifteen minutes. Ung. atrop. 1 per cent. was put in and the eye tied up. The bathing was done daily. The pain and lacrimation soon disappeared and after ten days the solution could be instilled without cocain which is only necessary while the eye is red.

The little particles of calcium carbonate could be seen to be gradually getting less, and his vision from counting fingers, after six weeks was $6 / 6$ with his correction of $-1 D$. sph. and -0.5 cyl. There are still, however, peripheral nebulae which most probably are due to the direct action of the burn and will therefore not respond to treatment.

The second case was seen in April, 1924. This patient had had treatment for one month before admission. There was much opacity of the cornea and the little white particles were there as before. His vision was $6 / 60$. After two months treatment with the tartrate solution it was brought to $6 / 12$. This man also showed the peculiarity noted in several of the cases that although he was under atropin all the time and there were no synechiae, his pupil would not dilate freely.

These two cases show what results may be achieved in early and late cases, and very probably as zur Nedden says the opacities may be improved years after the injury.

I asked Mr. Hampshire, Pharmacist to University College Hospital to try the effect of 10 per cent. neutral ammonium tartrate on calcium carbonate in vitro. He kindly did this and writes as follows :

"The action of 10 per cent. ammonium tartrate in the treatment of lime burns of the cornea seems to be simply a conversion of the insoluble calcium carbonate into the slightly more soluble calcium tartrate, which is washed away.

$$
\mathrm{CaCO}_{3}+\left(\mathrm{NH}_{4}\right)_{2} \mathrm{C}_{4} \mathrm{H}_{4} \mathrm{O}_{6}=\mathrm{CaC}_{4} \mathrm{H}_{4} \mathrm{O}_{6}+\left(\mathrm{NH}_{4}\right)_{2} \mathrm{CO}_{3} \text {. }
$$

This reaction takes place slowly, hence the need for the prolonged treatment. I put some calcium carbonate into a 10 per cent. solution of ammonium tartrate and after a few days, found that the insoluble powder had been replaced by crystals of calcium tartrate which of course, could have been dissolved up by adding more water."

I have seen several cases since both at University College Hospital and at Moorfields, the result of treatment being uniformly good, and Mr. Humphrey, House Surgeon at the latter hospital, tells me that the tartrate is now used as a routine.

My thanks are due to Sir John Parsons, under whose care the cases I have described were, for allowing me in the first instance to try the solution and secondly to publish the results of the treatment. 